\title{
Clinical manifestations and treatment of adult-onset asthma and periocular xanthogranuloma
}

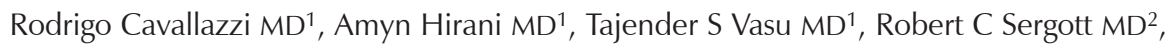 \\ Jurij R Bilyk $M D^{2}$, Ralph C Eagle $M D^{2}$, Sandra Weibel $M D^{1}$
}

\begin{abstract}
R Cavallazzi A Hirani, TS Vasu, et al. Clinical manifestations and treatment of adult-onset asthma and periocular xanthogranuloma. Can Respir J 2009;16(5):159-162.
\end{abstract}

BACKGROUND: Adult-onset asthma and periocular xanthogranuloma is an uncommon and recently described disease. Little is known about the condition because only a few case reports and series are available.

OBJECTIVE/METHODS: To describe the clinical manifestations, lung physiology, and response to systemic treatment of three patients with adult-onset asthma and periocular xanthogranuloma, followed by a review of the literature.

RESULTS: Three men, with an age at diagnosis ranging from 48 to 51 years, presented with right periorbital swelling, asthma and chronic rhinosinusitis. The patients' lung physiology was consistent with airway obstruction. Diagnosis was established by periorbital biopsy. All patients received oral corticosteroids for their periorbital swelling, without significant clinical response. Two patients received oral methotrexate, with nearly complete resolution of periorbital swelling. A third patient received oral azathioprine, without clinical response. The three patients had improvement of their asthma with inhaled steroids/long-acting bronchodilator, and immunosuppressive medication.

CONCLUSION: A triad consisting of periorbital swelling, asthma and chronic rhinosinusitis should raise the suspicion of adult-onset asthma and periocular xanthogranuloma. Oral methotrexate should be considered as an alternative to corticosteroids in the treatment of this disorder.

Key Words: Adult; Asthma, Glucocorticoids; Methotrexate; Orbital diseases; Xanthomatosis

$\mathrm{X}$ anthogranulomatous diseases are non-Langerhans cell forms of histiocytosis, and in adults include ErdheimChester disease, adult-onset xanthogranuloma, adult-onset asthma and periocular xanthogranuloma, and necrobiotic xanthogranuloma $(1,2)$. The common features of all these diseases are the presence of foamy histiocytes and Touton giant cells. The occurrence and type of systemic manifestations are important for differentiating these conditions because histological findings are similar (1).

While Erdheim-Chester disease causes diffuse infiltration of organs and bones, and presents mainly with bone pain (3), adult-onset asthma and periocular xanthogranuloma is characterized by orbital and eyelid lesions, asthma symptoms and immune dysfunction (1). Adult-onset xanthogranuloma presents solely with periorbital symptoms. Necrobiotic xanthogranuloma manifests as discrete, slowly developing, red skin lesions that consist of nodules and plaques, with a tendency to ulcerate. They predominantly affect the face (4).

The focus of the present article is adult-onset asthma and periocular xanthogranuloma. We decided to report on the cases seen in the Division of Pulmonary and Critical Care Medicine, Thomas Jefferson University (Philadelphia, USA), because adult-onset asthma and periocular xanthogranuloma is

\section{Manifestations cliniques et traitement de l'asthme adulte avec xanthogranulome périoculaire}

HISTORIQUE : L'asthme adulte avec xanthogranulome périoculaire est une entité rare qui a récemment été décrite. On en connaît peu au sujet de la maladie en raison du faible nombre de cas et de séries.

OBJECTIF ET MÉTHODES : Décrire les manifestations cliniques, la physiologie pulmonaire et la réponse au traitement systémique de trois patients atteints d'asthme adulte avec xanthogranulome périoculaire et procéder à une revue de la littérature.

RÉSULTATS : Trois hommes âgés de 48 à 51 ans au moment du diagnostic ont présenté un œdème périorbital droit, de l'asthme et une rhinosinusite chronique. La physiologie pulmonaire des patients concordait avec une obstruction respiratoire. Le diagnostic a été établi lors d'une biopsie périorbitale. Tous les patients ont reçu des corticostéroïdes oraux pour leur œdème périorbital, sans réponse clinique significative. Deux patients ont alors reçu du méthotrexate par voie orale et ont obtenu une résolution quasi complète de leur œdème périorbital. Le troisième patient a reçu de l'azathioprine par voie orale sans obtenir de réponse clinique. Les trois patients ont vu leur asthme s'améliorer avec des corticostéroïdes/broncho-dilatateurs à longue action par inhalation et un immunosuppresseur.

CONCLUSIONS : La triade composée d'œdème périorbital, d'asthme et de rhinosinusite chronique devrait éveiller les soupçons quant à l'asthme adulte avec xanthogranulome périoculaire. On peut envisager du méthotrexate par voie orale comme solution de rechange aux corticostéroïdes pour le traitement de cette maladie

an uncommon and poorly recognized disease - the few case reports and series found in the literature do not describe lung physiology and, other than corticosteroids, experience with the systemic treatment of this condition is scarce.

\section{CASE PRESENTATIONS}

Three cases of adult-onset asthma and periocular xanthogranuloma are reported, followed by a review of the literature pertaining to this disease. Asthma severity was classified according to guidelines published in an expert panel report in 2007 (5).

Table 1 summarizes clinical information, treatment and outcomes of the three patients in the present study, with pulmonary function test data presented in Table 2 .

\section{Patient 1}

A 51-year-old Caucasian man presented with a four-year history of right periorbital swelling. The swelling was painless, with no diminished or double vision reported. Three years previously, the patient underwent a right periorbital biopsy that revealed benign lymphoid hyperplasia. After biopsy, he received oral methylprednisolone for three weeks, which resulted in a partial reduction of swelling. However, the swelling rapidly recurred once methylprednisolone was tapered. Concomitant

${ }^{1}$ Division of Pulmonary and Critical Care Medicine; ${ }^{2}$ Wills Eye Institute, Department of Opthalmology, Thomas Jefferson University Hospital,

Philadelphia, Pennsylvania, USA

Correspondence: Dr Rodrigo Cavallazzi, Thomas Jefferson University, 834 Walnut Street, Suite 650, Philadelphia,

Pennsylvania 19107, USA. Telephone 215-955-6591, fax 215-955-0830, e-mail rodrigo.cavallazzi@jeffersonhospital.org 
TABLE 1

Clinical information, treatment and outcome of patients with adult-onset asthma and periocular xanthogranuloma

\begin{tabular}{|c|c|c|c|c|c|c|c|c|c|}
\hline \multirow[b]{2}{*}{ Patient } & \multirow[b]{2}{*}{ Sex } & \multicolumn{2}{|c|}{ Age, years } & \multirow[b]{2}{*}{$\begin{array}{c}\text { Clinical } \\
\text { presentation }\end{array}$} & \multirow[b]{2}{*}{ Comorbidities } & \multirow[b]{2}{*}{$\begin{array}{l}\text { Asthma } \\
\text { severity }\end{array}$} & \multirow[b]{2}{*}{ Treatment } & \multirow[b]{2}{*}{ Outcome } & \multirow[b]{2}{*}{$\begin{array}{l}\text { Follow-up } \\
\text { time, years }\end{array}$} \\
\hline & & $\begin{array}{l}\text { At onset of } \\
\text { symptoms }\end{array}$ & $\begin{array}{c}\text { At } \\
\text { diagnosis }\end{array}$ & & & & & & \\
\hline 1 & Male & 47 & 51 & $\begin{array}{l}\text { Right periorbital } \\
\text { swelling }\end{array}$ & $\begin{array}{l}\text { Asthma, rhinosinusitis, } \\
\text { type } 2 \text { diabetes } \\
\text { mellitus, high blood } \\
\text { pressure }\end{array}$ & Severe & $\begin{array}{l}\text { Oral corticosteroid } \\
\text { followed by } \\
\text { oral methotrexate } \\
\text { and inhaled steroid/ } \\
\text { long-acting } \\
\text { bronchodilator }\end{array}$ & $\begin{array}{l}\text { Nearly complete resolution } \\
\text { of periorbital swelling. } \\
\text { Asthma well controlled }\end{array}$ & 1.5 \\
\hline 2 & Male & 47 & 48 & $\begin{array}{l}\text { Right eye red- } \\
\text { ness followed } \\
\text { by periorbital } \\
\text { swelling }\end{array}$ & $\begin{array}{l}\text { Asthma, rhinosinusitis, } \\
\text { nasal polyps, type } 2 \\
\text { diabetes mellitus }\end{array}$ & Moderate & $\begin{array}{l}\text { Oral corticosteroid } \\
\text { followed by } \\
\text { oral methotrexate and } \\
\text { inhaled steroid/long- } \\
\text { acting bronchodilator }\end{array}$ & $\begin{array}{l}\text { Nearly complete resolution } \\
\text { of periorbital swelling. } \\
\text { Asthma well controlled }\end{array}$ & 2 \\
\hline 3 & Male & 46 & 51 & $\begin{array}{l}\text { Right periobital } \\
\text { swelling }\end{array}$ & $\begin{array}{l}\text { Asthma, rhinosinusitis, } \\
\text { nasal polyps, chronic } \\
\text { hepatitis } \mathrm{C} \text {, type } 2 \\
\text { diabetes mellitus }\end{array}$ & Mild & $\begin{array}{l}\text { Oral corticosteroid } \\
\text { followed by oral } \\
\text { azathioprine and } \\
\text { inhaled steroid }\end{array}$ & $\begin{array}{l}\text { No change in periorbital } \\
\text { swelling. Asthma well } \\
\text { controlled }\end{array}$ & 0.5 \\
\hline
\end{tabular}

TABLE 2

Pulmonary function test data of patients with adult-onset asthma and periocular xanthogranuloma

\begin{tabular}{|c|c|c|c|c|c|c|c|}
\hline \multirow[b]{2}{*}{ Patient } & \multicolumn{3}{|c|}{ Prebronchodilator, L (\% predicted) } & \multirow{2}{*}{$\begin{array}{l}\text { Post-bronchodilator } \\
\text { FEV }_{1} \text {, L ( } \% \text { predicted) }\end{array}$} & \multicolumn{3}{|c|}{ Post-treatment, L (\% predicted) } \\
\hline & FVC & FEV $_{1}$ & FEV $_{1} /$ FVC & & FVC & FEV $_{1}$ & FEV $_{1} /$ FVC \\
\hline 1 & $3.12(56)$ & $1.79(40)$ & 57 & $2.58(57)$ & $4.67(84)$ & $3.62(81)$ & 77 \\
\hline 2 & $3.43(86)$ & $2.18(67)$ & 64 & $2.74(84)$ & $2.65(67)$ & $2.47(76)$ & 93 \\
\hline 3 & $4.68(97)$ & $3.02(85)$ & 65 & $3.5(99)$ & $4.56(95)$ & $3.39(95)$ & 74 \\
\hline
\end{tabular}

FEV 1 Forced expiratory volume in $1 \mathrm{~s}$; FVC Forced vital capacity

with periocular manifestations, he developed severe asthma and chronic rhinosinusitis symptoms. The patient's medical history was significant for type 2 diabetes mellitus and high blood pressure. He was a former smoker with a 30 pack-year history who quit five years previously. A physical examination was remarkable for the presence of a swollen, rubbery, right upper eyelid, without tenderness. The patient's vision was 20/20 on the right and 20/25 on the left, with no afferent pupillary defect or extraocular motility impairment. Serum protein electrophoresis and immunoglobulin (Ig) quantitation were normal. Laboratory results showed an absolute eosinophil count of 640 cells/ $\mathrm{LL}(8.2 \%)$. He had a positive skin test to common allergens. The initial pulmonary function test was consistent with airway obstruction, with significant response to bronchodilators (Table 2). A repeat right lacrimal gland biopsy was performed at our institution that revealed xanthogranulomatous inflammation with Touton giant and histiocytic cells. He received oral methotrexate, started at $5 \mathrm{mg}$ once weekly and gradually increased to $20 \mathrm{mg}$ once weekly, and inhaled fluticasone $250 \mu \mathrm{g}$ with $50 \mu \mathrm{g}$ salmeterol twice a day. After initiation of both methotrexate and inhaled steroid/ long-acting bronchodilator, the patient had nearly complete resolution of his right periorbital swelling and his asthma was well controlled. While the asthma symptoms had subsided by the time of his follow-up visit three months after initiation of therapy, resolution of the periorbital swelling took longer than 1.5 years.

\section{Patient 2}

A 48-year-old Caucasian man presented to the outpatient clinic with a one-year history of right eye redness. Initially, the patient was diagnosed with allergic conjunctivitis and treated with azelastine ophthalmic solution. Subsequently, he noticed right periorbital swelling and binocular diplopia. He was treated with oral corticosteroid without improvement of the swelling. He admitted to asthma, chronic rhinosinusitis and nasal polyps (all three conditions diagnosed 10 years previously and treated with inhaled steroids), as well as type 2 diabetes mellitus. The patient had daily asthma symptoms of moderate severity. He reported being a former smoker with a 24 packyear history who quit nine years previously. Physical examination revealed redness over the lateral portion of the right conjunctiva, and a $6 \mathrm{~mm}$ proptosis on the right. The right lower eyelid was swollen and had a yellow plaque. The patient's vision was 20/40 on the right and 20/20 on the left, with no afferent pupillary defect. Extraocular motility was preserved but he developed diplopia on left end gaze. A pulmonary function test initially demonstrated airway obstruction, with significant bronchodilator response (Table 2). He had a positive skin test to common allergens. Laboratory investigation showed an absolute eosinophil count of 600 cells/ $\mu \mathrm{L}$ (7\%). A computed tomography scan of the orbits revealed enlargement of the extraocular muscles on the right side (Figure 1). He underwent biopsy of the anterior orbital tissue, the result of which evidenced chronic inflammation consisting of lymphoid follicles, fat necrosis and focal foamy histiocytes suggestive of xanthoma cells. He received oral methotrexate, started at $5 \mathrm{mg}$ once weekly and gradually increased to $20 \mathrm{mg}$ once weekly, and was continued on fluticasone $250 \mu \mathrm{g}$ with salmeterol $50 \mu \mathrm{g}$ twice a day. He had nearly complete resolution of swelling and his asthma was well controlled after the initiation of methotrexate. 


\section{Patient 3}

A 51-year-old Caucasian man presented to the outpatient clinic with a five-year history of right periobital swelling. He received oral methylprednisolone for the swelling, with no improvement. He reported mild asthma, chronic rhinosinusitis and nasal polyps that initially manifested at the same time as the onset of periobital swelling. The patient's medical history was also significant for chronic hepatitis $\mathrm{C}$ and type 2 diabetes mellitus. He was smoker with a 30 pack-year history, but quit 10 years previously. Physical examination revealed preseptal swelling in the right upper eyelid. The patient's vision was 20/20 in both eyes, and there was no afferent pupillary defect or extraocular motility impairment. Serum protein electophoresis was normal. There was no peripheral eosinophilia. He had a positive skin test to common allergens. Pulmonary function tests initially revealed airway obstruction with significant bronchodilator response (Table 2). He underwent biopsy of the anterior orbital tissue, the results of which showed Touton giant and histiocytic cells consistent with xanthogranulomatous inflammation (Figure 2). Because he had previously received oral corticosteroid without response, and chronic liver disease is a relative contraindication for methotrexate, he received oral azathioprine at $25 \mathrm{mg}$ twice a day. He also received inhaled beclomethasone $160 \mu \mathrm{g}$ twice a day. His clinical response to azathioprine was not significant; however, his asthma was well controlled.

\section{DISCUSSION}

In 1993, Jakobiec et al (6) reported on six patients who presented with periocular manifestations and histological findings similar to Erdheim-Chester disease; however, a striking feature of that group of patients was that five had adult-onset asthma that started at approximately the same time as the periocular manifestations in at least three patients. Equally noticeable was that their patients lacked the systemic manifestations commonly seen in Erdheim-Chester disease. The authors designated these cases as periocular xanthogranulomas associated with adult-onset asthma, and proposed that they may represent a separate clinicopathological entity. Recently, Sivak-Callcott et al (1) have used the term adult-onset xanthogranuloma to label patients who present solely with a xanthogranulomatous lesion, while the term adult-onset asthma and periocular xanthogranuloma denotes a syndrome in which a xanthogranulomatous lesion is associated with asthma and, often, reactive lymphadenopathy and increased IgG levels.

The majority of patients with adult-onset asthma and periocular xanthogranuloma are diagnosed in their fourth or fifth decade of life; however, age at diagnosis varies broadly (6-8). The disease involves both sexes, although it has been reported with higher frequency in men $(2,7-9)$. It is unknown whether there is a race or ethnic group category predilection.

The main clinical presentations are periorbital swelling that is often painless and slow growing, and erythematous or yellow plaques on the eyelids $(2,6)$. There have been reports of unilateral and bilateral periocular involvement (6). In some instances, although signs and symptoms are unilateral, imaging studies demonstrate bilateral disease. Furthermore, some patients initially present with unilateral disease and later manifest bilateral involvement. Diplopia, a less common symptom, can be present when the disease affects the extraocular muscles (7). The swelling is firm, rubbery and usually located in the

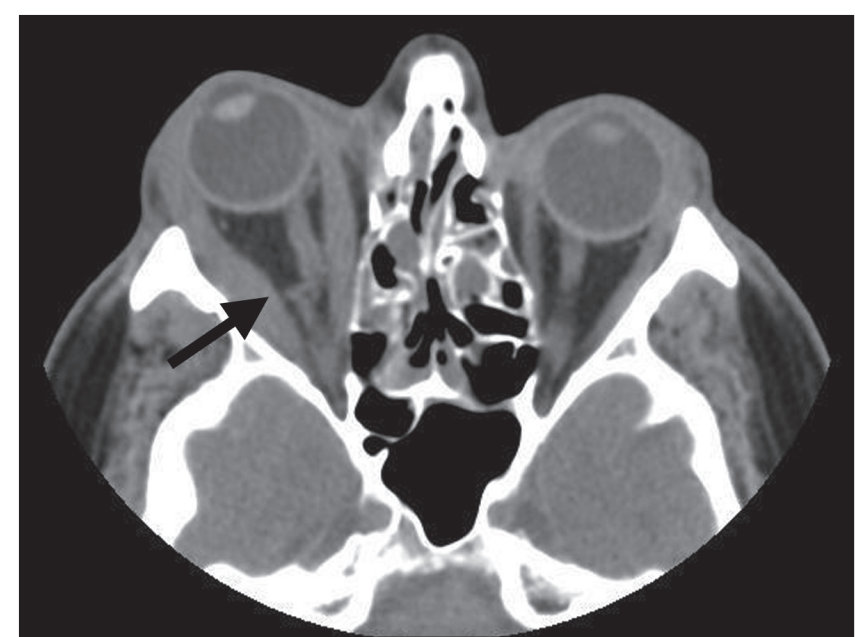

Figure 1) A computed tomography scan giving an axial view of the orbit, showing proptosis secondary to diffuse enlargement of the extraocular muscles on the right side (arrow on right lateral rectus)

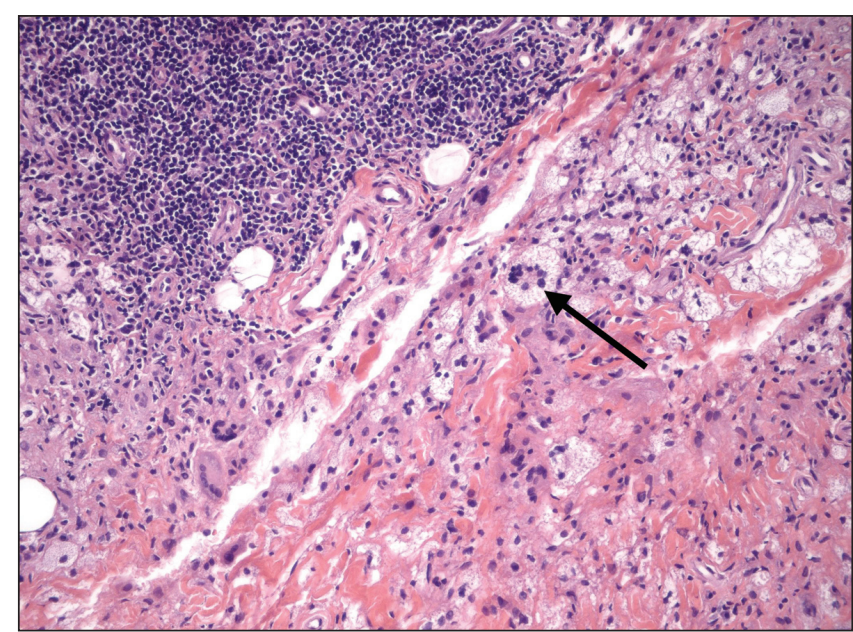

Figure 2) Periorbital tissue biopsy from patient 3. Note the histiocytic infiltrate, germinal centre formation and Touton giant cell (arrow). Hematoxylin and eosin, original magnification $\times 50$

preseptal and anterior orbital areas $(1,6,10)$. In addition to eyelid swelling and plaques, physical examination can disclose proptosis, ptosis and extraocular motility limitation $(11,12)$.

Asthma tends to appear at approximately the same time as the periocular manifestations (6). However, this is not always the rule because one of our patients had asthma for nine years before the onset of periocular symptoms. Pulmonary function testing of our patients showed airway obstruction, with significant response to bronchodilators. Chronic sinusitis and nasal polyps have been reported in some cases $(2,6,9)$. All patients in our series had chronic rhinosinusitis, with two having nasal polyps; however, none of our patients had a history of adverse reactions to acetylsalicylic acid or other nonsteroidal anti-inflammatory drugs. The pathogenesis of asthma with this condition is unclear but the probable role of eosinophil recruitment and activation is highlighted by reports of both peripheral eosinophilia and eosinophilic tissue infiltrate in the periorbital biopsy (6). The accumulation of non-Langerhans histiocytes in the periorbital tissue implies an activation of the mononuclear phagocytic system, and it is known that dendritic 
cells located in the airway epithelium and submucosa are important in initiating and maintaining immune responses to inhaled allergens (13). Reactive lymphadenopathy and increased IgG levels noted in some patients indicates that a systemic immunological derangement is present (1), which is likely to upregulate the immune and inflammatory reactions involved in the pathogenesis of asthma. Skin test positivity to common allergens also reveals a predisposition to IgE-mediated reactions in these patients. Other potential disease associations include diabetes mellitus and lymphoplasmacytic sclerosing pancreatitis $(6,7,9)$.

In the appropriate clinical scenario, the diagnosis of adultonset asthma and periocular xanthogranuloma is established when a periorbital biopsy reveals the characteristic histological findings: non-Langerhans, lipid-laden histiocytes, Touton giant cells and lymphoid aggregates with germinal centres $(1,6)$. Features on electron microscopy and immunohistochemistry aid in the differentiation of non-Langerhans from Langerhans cells. For example, while Langerhans cells are identified by the presence of intracytoplasmic Birbeck granules and positive reaction to S-100 protein and CD1a, non-Langerhans cells are characterized by the expression of different surface markers (blood-clotting transglutaminase Factor XIIIa, CD68, Mac387 and vimentin) and the absence of Birbeck granules (12).

It is not uncommon for patients to be seen by several physicians and undergo more than one periorbital biopsy before the diagnosis is established (2). The time from onset of symptoms to diagnosis in our patients ranged from one to five years. Clinically, the differential diagnosis includes other histiocytic disorders with periorbital involvement as well as conditions that cause orbital space-occupying masses such as malignancy and sarcoidosis (14). Case reports and the present series have indicated that the periorbital manifestations of adult-onset asthma and periocular xanthogranuloma are frequently confused with xanthelasma and Graves' disease $(6,8)$. In a patient with periorbital swelling, the presence of asthma, chronic rhinosinusitis or nasal polyps most likely infers a diagnosis of adultonset asthma and periocular xanthogranuloma.

Due to the rare nature of this disease, therapeutic strategies are based on anecdotal experience. Local forms of treatment include surgery, radiation and intralesion corticosteroid administration. Systemic treatment includes oral forms of corticosteroid, methotrexate and other cytotoxic medications. Oral corticosteroids have been the most commonly used systemic treatment for both adult-onset xanthogranuloma and adult-onset asthma and periocular xanthogranuloma; however, clinical response is often only partial, with several authors reporting the recurrence of symptoms on tapering the medication $(6,7,9,10,15)$.

Methotrexate is a competitive inhibitor of dihydrofolate reductase, and is a cytotoxic agent widely used for the treatment of malignancy and inflammatory conditions. The inhibition of dihydrofolate reductase, with subsequent impaired thymidylate and DNA synthesis, is the mechanism by which methotrexate effects the treatment of cancer. However, the anti-inflammatory effect of low-dose methotrexate may not be due entirely to the inhibition of dihydrofolate reductase; instead, the stimulation of adenosine release and the reduced production of cytokines appear to be the important mechanisms
(16). In the study reported by Hayden et al (7), three patients with orbital xanthogranuloma received oral methotrexate. One patient did not tolerate the medication but two responded well, with significant decrease of skin discolouration and ptosis.

\section{SUMMARY}

The present study shows that the results of lung function testing in patients with adult-onset asthma and periocular xathogranuloma are consistent with obstructive airway physiology, and correlate with asthma symptoms. Furthermore, chronic rhinosinusitis and nasal polyps are important accompaniments of this disease. Finally, our treatment experience, similar to other authors (7), suggests that methotrexate has a role in the systemic treatment of this disorder. While it is unclear whether methotrexate should be used as a first-line systemic therapy, its use should be considered when corticosteroids fail or as a steroid-sparing agent in patients unable to be tapered off corticosteroids.

\section{REFERENCES}

1. Sivak-Callcott JA, Rootman J, Rasmussen SL, et al. Adult xanthogranulomatous disease of the orbit and ocular adnexa: New immunohistochemical findings and clinical review. Br J Ophthalmol 2006;90:602-8.

2. Vick VL, Wilson MW, Fleming JC, Haik BG. Orbital and eyelid manifestations of xanthogranulomatous diseases. Orbit 2006;25:221-5.

3. Veyssier-Belot C, Cacoub P, Caparros-Lefebvre D, et al. ErdheimChester disease. Clinical and radiologic characteristics of 59 cases. Medicine (Baltimore) 1996;75:157-69.

4. Finan MC, Winkelmann RK. Necrobiotic xanthogranuloma with paraproteinemia. A review of 22 cases. Medicine (Baltimore) 1986;65:376-88.

5. National Asthma Education and Prevention Program. Expert Panel Report 3 (EPR-3): Guidelines for the Diagnosis and Management of Asthma - Summary Report 2007. J Allergy Clin Immunol 2007;120(Suppl 5):S94-138.

6. Jakobiec FA, Mills MD, Hidayat AA, et al. Periocular xanthogranulomas associated with severe adult-onset asthma. Trans Am Ophthalmol Soc 1993;91:99,125; discussion 125-9.

7. Hayden A, Wilson DJ, Rosenbaum JT. Management of orbital xanthogranuloma with methotrexate. Br J Ophthalmol 2007;91:434-6.

8. Hammond MD, Niemi EW, Ward TP, Eiseman AS. Adult orbital xanthogranuloma with associated adult-onset asthma. Ophthal Plast Reconstr Surg 2004;20:329-32.

9. Roggin KK, Rudloff U, Klimstra DS, Russell LA, Blumgart LH. Adult-onset asthma and periocular xanthogranulomas in a patient with lymphoplasmacytic sclerosing pancreatitis. Pancreas 2007;34:157-60.

10. Zoumalan CI, Erb MH, Rao NA, et al. Periorbital xanthogranuloma after blepharoplasty. Br J Ophthalmol 2007;91:1088-9.

11. Elner VM, Mintz R, Demirci H, Hassan AS. Local corticosteroid treatment of eyelid and orbital xanthogranuloma. Trans Am Ophthalmol Soc 2005;103:69,73; discussion 73-4.

12. Karcioglu ZA, Sharara N, Boles TL, Nasr AM. Orbital xanthogranuloma: Clinical and morphologic features in eight patients. Ophthal Plast Reconstr Surg 2003;19:372-81.

13. Hammad H, Lambrecht BN. Dendritic cells and epithelial cells: Linking innate and adaptive immunity in asthma. Nat Rev Immunol 2008;8:193-204.

14. Rose GE, Patel BC, Garner A, Wright JE. Orbital xanthogranuloma in adults. Br J Ophthalmol 1991;75:680-4.

15. Nasr AM, Johnson T, Hidayat A. Adult onset primary bilateral orbital xanthogranuloma: Clinical, diagnostic, and histopathologic correlations. Orbit 1991;10:13-22.

16. Marder W, McCune WJ. Advances in immunosuppressive therapy. Semin Respir Crit Care Med 2007;28:398-417. 


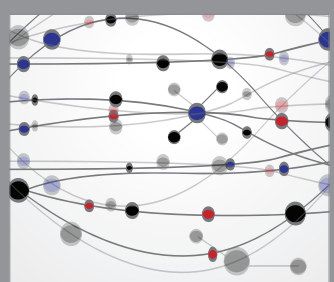

The Scientific World Journal
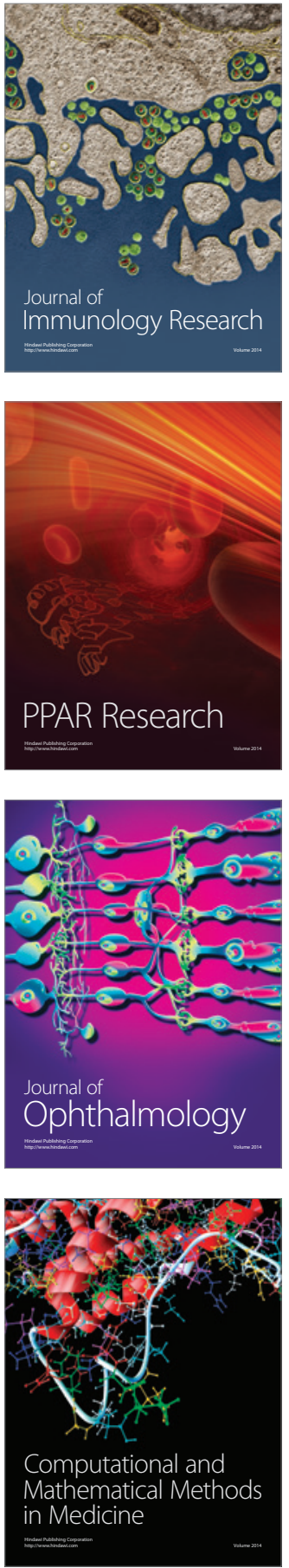

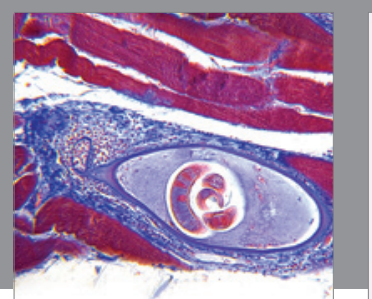

Gastroenterology Research and Practice

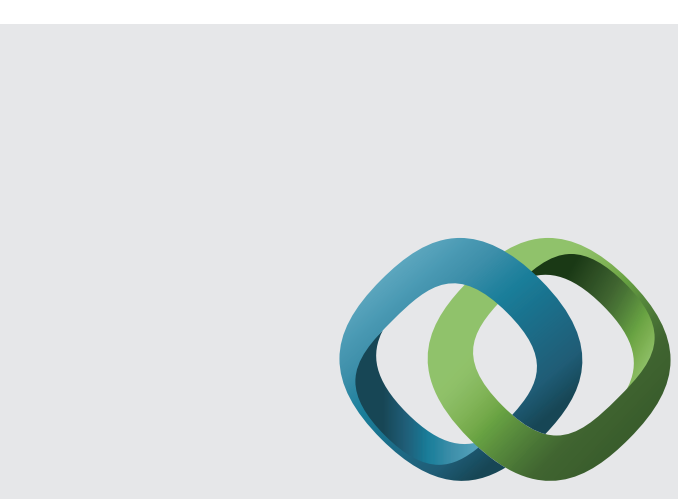

\section{Hindawi}

Submit your manuscripts at

http://www.hindawi.com
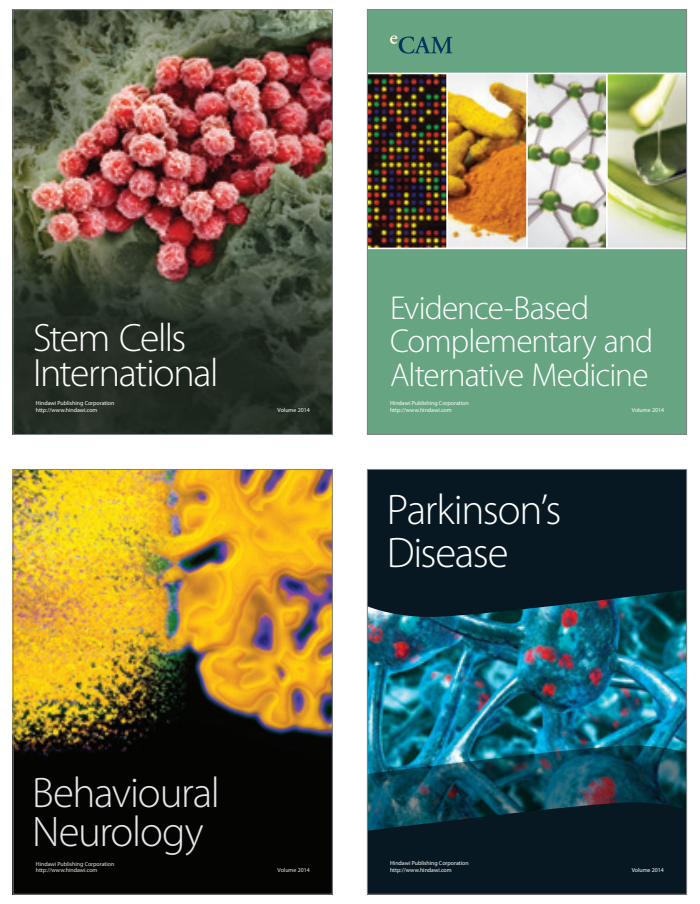
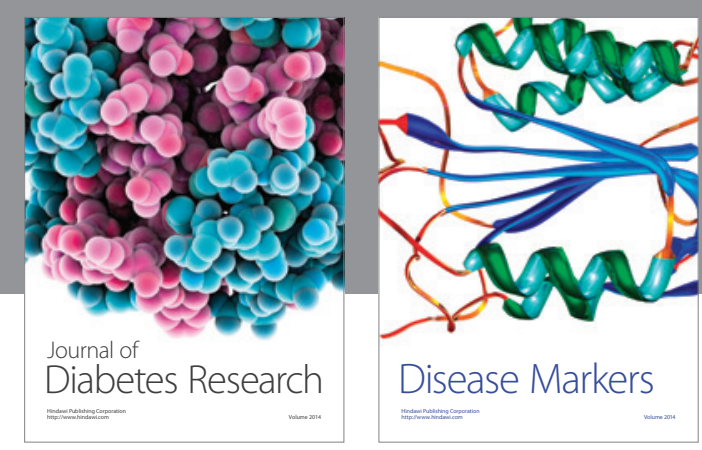

Disease Markers
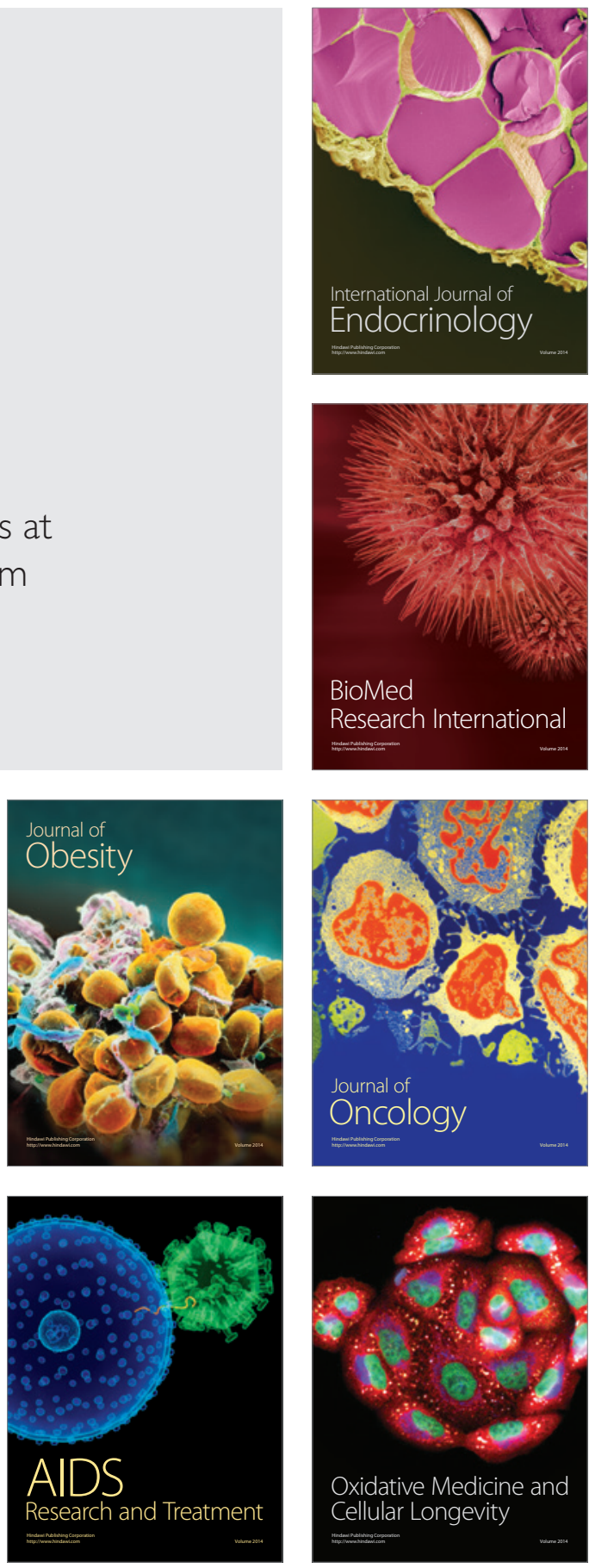